\title{
SOVIET RESEARCHERS STUDY ENGLISH HISTORY
}

To meet the growing interest of the Soviet public in England of the past and present, at the beginning of the war a special research section on English history was established at the Institute of History. The results of these researches were given in the form of reports, papers and lectures. They dealt with a number of problems about England in the middle ages and modern times. Several reports dealt with the agrarian history of England. The study of this aspect of English history has a long tradition in Russia, dating back to the wellknown historian Pavel Vinogradov. Several reports on the development of the English village from the eleventh to the eighteenth century were prepared by Prof. L. Kosminsky, V. Lavrovsky and Barg. Associate Prof. Y. Levitsky wrote a paper on English cities of the eleventh century, based on the Domesday Book. Studies by E. Gutnova dealt with problems of medieval English history. One of the topics receiving most attention was that of the English Revolution in the seventeenth century, particularly the colonial and foreign policy pursued by Cromwell. This subject was treated in papers by Profs. S. Arkhangelsky, A. Samoilo and V. Semenov. In them Cromwell was characterised as a great military leader and diplomat, the founder of England's prestige abroad and of the British colonial empire. N. Dmitrievsky's paper dealt with the new principles introduced into the English courts by the English Revolution. Considerable interest was aroused by the reports on economic and political relations between Russia and England in the period from the sixteenth century to the present. This subject was treated by A. Savich, Y. Lurye and I. Zvavich. The last report in this series ontlined English diplomacy in 1812 as shown in the parliamentary debates of the period. Prof. V. Vasyutinsky prepared a series of papers on the history of Scotland in the seventeenth century. Several papers were read on the history of social thought in England. E. Gutnova prepared a paper on Thomas Carlyle. Another, on Macaulay, was read by K. Tatarnikova. A report by Prof. E. Kosminsky on the specific characteristics of English history drew a large audience. 